\title{
EFEKTIVITAS MODEL PEMBELAJARAN KOOPERATIF TIPE NUMBERED HEAD TOGETHER (NHT) DAN MAKE A MATCH TERHADAP PRESTASI BELAJAR MATEMATIKA SISWA DITINJAU DARI KETERAMPILAN SOSIAL SISWA PADA KELAS X SMK DI KABUPATEN WONOGIRI TAHUN AJARAN 2012/2013
}

\author{
Nuryani Destiningsih $^{1}$, Budi Usodo ${ }^{2}$ dan Mardiyana $^{3}$ \\ ${ }^{1}$ Sekolah Menengah Kejuruan Negeri 1 Pracimantoro, KabupatenWonogiri \\ ${ }^{2,3}$ Prodi Magister Pendidikan Matematika, PPs Universitas Sebelas Maret Surakarta
}

\begin{abstract}
Abstrak. Tujuan penelitian ini adalah untuk mengetahui : ( 1 ) yang memberikan matematika yang lebih baik prestasi belajar, penggunaan kooperatif tipe model pembelajaran NHT, Membuat Pertandingan atau pembelajaran langsung , ( 2 ) yang memberikan matematika yang lebih baik prestasi belajar, peserta didik dengan tinggi, sedang, atau rendah tingkat keterampilan sosial, ( siswa dengan tinggi, sedang, atau rendahnya tingkat keterampilan sosial , ( 3 ) di masing-masing keterampilan sosial, mana yang memberikan matematika yang lebih baik prestasi, model pembelajaran kooperatif tipe NHT, Membuat Match . atau pembelajaran langsung , ( 4 ) masingmasing model pembelajaran, mana yang memberikan matematika yang lebih baik prestasi, siswa yang memiliki tinggi, sedang, atau keterampilan sosial yang rendah penelitian ini merupakan penelitian kuasi - eksperimental kesimpulan dari penelitian ini adalah : . ( 1 ) prestasi matematika siswa yang menggunakan pembelajaran kooperatif tipe model NHT lebih baik daripada siswa yang menggunakan model pembelajaran kooperatif Membuat Jenis pencocokan atau instruksi langsung, sedangkan siswa matematika prestasi yang menggunakan model pembelajaran kooperatif Membuat Jenis pencocokan lebih baik daripada belajar langsung , ( 2 ) siswa yang memiliki keterampilan sosial yang tinggi dan menengah, sehingga prestasi matematika yang sama , sedangkan siswa yang memiliki keterampilan sosial yang tinggi dan menengah memiliki prestasi matematika yang lebih baik adalah dari siswa yang memiliki keterampilan sosial yang rendah, ( 3 ) pada setiap keterampilan sosial ( tinggi, menengah, dan rendah ), siswa matematika prestasi yang menggunakan model pembelajaran kooperatif tipe NHT lebih baik dari siswa yang menggunakan model pembelajaran kooperatif Membuat Jenis pencocokan atau instruksi langsung , dan siswa yang menggunakan model pembelajaran kooperatif Membuat Jenis pencocokan memiliki lebih baik daripada prestasi matematika hands- on belajar , ( 4 ) pada masing-masing model pembelajaran ( NHT , Membuat Match, dan belajar langsung ), siswa yang memiliki keterampilan sosial yang tinggi dan menengah, memiliki prestasi matematika yang sama , sedangkan siswa yang memiliki keterampilan sosial yang tinggi dan menengah matematika yang lebih baik daripada prestasi siswa yang memiliki keterampilan sosial yang rendah belajar .
\end{abstract}

Kata kunci: Numbered Head Together ( NHT ), Membuat Match, pembelajaran langsung, dan keterampilan sosial.

\section{PENDAHULUAN}

Matematika dianggap sebagai

mata pelajaran yang sulit,

membosankan, banyak rumus dan

hitungannya, juga guru matematika yang

kurang kreatif dalam mengkondisikan

siswa untuk terampil bekerja secara

kelompok saat pembelajaran. Proses pembelajaran di sekolah-sekolah belum sesuai dengan apa yang diharapkan, dikarenakan umumnya guru yang mengajar masih banyak yang bersifat konvensional atau bisa disebut menggunakan model pembelajaran langsung. Guru sebagai sumber belajar, 
sehingga hanya terfokus pada guru. Pembelajaran yang tidak mengajak siswa untuk lebih aktif, dan guru yang lebih mendominasi akan membuat siswa bosan dalam mengikuti pelajaran. Hal itu akan membuat hasil belajar siswa untuk tidak lebih baik, melainkan sebaliknya.

Berikut ini penelitian mengenai pembelajaran langsung dengan hanya menggunakan metode ceramah. Salah satunya penelitian yang dilakukan oleh Wahyu (2011:2) di SMP Se-Sub Rayon Wonogiri pada siswa kelas IX, mengemukakan bahwa pada proses pembelajaran matematika, siswa banyak yang kurang memahami apa yang disampaikan oleh guru. Hal itu membuat siswa bosan dan jenuh dan menyebabkan prestasi belajar matematika rendah. Hal tesebut dikarenakan penggunaan model pembelajaran yang masih bersifat konvensional, pembelajaran masih terpusat kepada guru. Dengan kata lain, pembelajaran langsung akan menyebabkan siswa menjadi tidak aktif dan membuat siswa merasa bosan.

Salah satu cara untuk mengoptimalkan potensi yang dimiliki siswa dalam kegiatan pembelajaran adalah dengan melibatkan siswa berperan aktif dalam proses pembelajaran. Melalui penerapan model pembelajaran yang inovatif, siswa akan lebih mampu dalam menyerap materi yang disampaikan. Model pembelajaran kooperatif merupakan model yang lebih mengutamakan kerja sama.

Menurut Suprijono (2009:54), pembelajaran kooperatif adalah pembelajaran yang lebih menekankan kepada konsep yang lebih luas meliputi semua jenis kerja kelompok termasuk bentuk-bentuk yang lebih dipimpin oleh guru atau diarahkan oleh guru. Model pembelajaran kooperatif menggambarkan keseluruhan proses sosial dalam belajar. Keterlibatan orang lain membuka kesempatan bagi mereka yang mengevaluasi dan memperbaiki pemahaman. Dengan cara ini, pengalaman dalam konteks sosial memberikan mekanisme penting untuk perkembangan pemikiran siswa. Konteks sosial dalam pembelajaran memang sangat penting khususnya dalam pembelajaran matematika. Dengan pembelajaran yang bersifat kooperatif siswa dapat bekerjasama menyelesaikan soal dengan berbagai pendapat siswa lain, sehingga pembelajaran menjadi lebih kreatif.

Faktor lain yang memengaruhi tidak optimalnya peningkatan prestasi belajar siswa adalah keterampilan sosial. Keterampilan sosial berhubungan dengan bagaimana siswa berhubungan 
dengan lingkungan sekitarnya. Keterampilan sosial yang dimaksudkan adalah keaktifan siswa berkomunikasi, bergaul dan berdiskusi dalam hal pelajaran matematika. Siswa yang cenderung pendiam dan kurang aktif tidak mempunyai keberanian untuk bertanya, berdiskusi dengan yang lainnya sehingga ketika mengalami kesulitan memahami materi akan cenderung diam. Siswa yang mampu berinteraksi aktif dengan temannya mempunyai kemungkinan meraih hasil belajar yang baik. Hal ini dikarenakan siswa tersebut mampu bersosialisasi ketika mengalami kesulitan dalam mengerjakan soal atau ketika belajar.

Penelitian yang dilakukan oleh Munawar (2009) menunjukkan bahwa setelah diterapkan cooperative learning tipe NHT, tingkat partisipasi belajar siswa dalam pembelajaran matematika di kelas mengalami peningkatan. Hasil belajar siswa dalam pembelajaran matematika juga mengalami peningkatan yaitu dari $61,40 \%$ meningkat menjadi $71,03 \%$. Peneliti Satyawati (2009) yang menggunakan model cooperative learning tipe Make a Match pun juga menyimpulkan bahwa minat belajar dan hasil belajar matematika siswa mengalami peningkatan yaitu dari 75\% meningkat menjadi 78,2\%. Hasil beberapa penelitian tersebut, membuat peneliti menggabungkan model pembelajaran NHT dan Make a Match yang ditinjau dari keterampilan sosial siswa.

\begin{tabular}{lllr}
\multicolumn{3}{c}{ Keterampilan sosial } & siswa \\
seperti yang dikatakan di & atas \\
mempunyai & pengaruh & & dalam
\end{tabular}
menentukan hasil belajar siswa dan hal ini selaras dengan penerapan NHT dan Make a Match yang membutuhkan keaktifan siswa. Keaktifan siswa dapat dibantu dengan memperhatikan keterampilan sosial siswa di kelas. Penelitian yang dilakukan nantipun juga memperhatikan hal tersebut sebagai bagian dari peningkatan terhadap hasil belajar siswa khususnya pada mata pelajaran matematika materi logaritma.

Berdasarkan ruang lingkup di atas, rumusan masalah penelitian adalah: (1) manakah yang memberikan prestasi belajar matematika yang lebih baik, penggunaan model pembelajaran kooperatif tipe NHT, Make a Match atau pembelajaran langsung, (2) manakah yang mempunyai prestasi belajar matematika yang lebih baik, siswa dengan keterampilan sosial yang tinggi, sedang atau rendah, (3) pada masingmasing keterampilan sosial, manakah yang memberikan prestasi belajar matematika lebih baik, model pembelajaran kooperatif tipe NHT, Make a Match atau pembelajaran 
langsung, (4) pada masing-masing model pembelajaran, manakah yang memberikan prestasi belajar matematika lebih baik, siswa yang memiliki keterampilan sosial tinggi, sedang, atau rendah.

\section{METODE PENELITIAN}

Penelitian ini merupakan penelitian eksperimental semu dengan desain penelitian $3 \times 3$. Budiyono (2009:121), menyatakan populasi adalah keseluruhan pengamatan yang ingin diteliti berhingga atau tak berhingga. Populasi pada penelitian ini adalah siswa kelas $\mathrm{X}$ SMK Negeri seKabupaten Wonogiri tahun ajaran 2012/2013. Penelitian dilakukan di SMK Pancasila 1 Wonogiri, SMK Gajah Mungkur 1 Wuryantoro, dan SMK Giri Wacana Eromoko dengan sampel 325 siswa. Dari masing-masing sekolah, secara acak diambil 3 kelas sebagai kelas eksperimen I, kelas eksperimen II, dan kelas kontrol. Teknik mengumpulkan data adalah: (1) metode dokumentasi; (2) metode angket; dan (3) metode tes. Instrumen penelitian terdiri atas: (1) tes penilaian hasil belajar matematika dan (2) angket keterampilan sosial. Variabel terikat adalah prestasi belajar matematika pada pokok bahasan logaritma, sedangkan variabel bebas yang pertama adalah model

pembelajaran yang terdiri atas kooperatif tipe NHTpada kelas eksperimen I, Make a Match pada kelas eksperimen II, dan pembelajaran langsung pada kelas kontrol. Variabel bebas yang kedua adalah keterampilan sosial dengan tiga kriteria yaitu tinggi, sedang, dan rendah.

Uji coba instrumen dilakukan di SMKN 1 Pracimantoro dengan responden masing-masing 50 siswa. Pada instrumen tes prestasi belajar, mengacu pada kriteria yaitu validitas isi, daya beda $\left(r_{x y} \geq 0,3\right)$, tingkat kesulitan $(0,3 \leq T K \leq 0,70) \quad$ dan $\quad$ reliabilitas 0,8843 , dari 30 butir soal yang diujicobakan didapat 25 butir soal yang baik, sehingga dapat digunakan sebagai instrumen tes prestasi belajar matematika siswa. Pada uji coba angket keterampilan sosial, mengacu pada kriteria yaitu validitas isi,reliabilitas Alpha Cronboch $\quad\left(r_{x y}=0,8723\right)$ dan konsistensi internal $\left(r_{x y} \geq 0,3\right)$, dari 30 butir pernyataan yang diujicobakan, diperoleh 28 butir pernyataan yang layak dijadikan sebagai instrumen angket keterampilan sosial siswa.

Selanjutnya dilakukan uji
normalitas dengan Liliefors, uji
homogenitas dengan uji Bartlett, dan
anava satu jalan digunakan untuk
mengetahui keseimbangan sampel.


Diperoleh hasil, kedua kelompok berasal dari populasi yang homogen, berdistribusi normal dan memiliki kemampuan awal yang sama. Uji prasyarat analisis yaitu uji normalitas dengan Liliefors dan uji homogenitas dengan uji Bartlett. Diperoleh prasyarat normalitas dan homogenitas data telah terpenuhi,sehingga dapat dilakukan analisis data menggunakan analisis variansi dua jalan dengan sel tak sama.

\section{HASIL PENELITIAN DAN PEMBAHASAN}

Rerata prestasi belajar matematika kelompok eksperimen (NHT dan Make a Match) dan kelompok kontrol (pembelajaran langsung) dapat dilihat dalam Tabel 1.

Tabel 1 Rerata Prestasi Belajar Berdasar Model Pembelajaran dan Keterampilan Sosial

\begin{tabular}{|c|c|c|c|c|}
\hline \multirow{2}{*}{ Kelompok } & \multicolumn{3}{|c|}{ Keterampilan Sosial } & \multirow{2}{*}{ Rerata Marginal } \\
\hline & Tinggi & Sedang & Rendah & \\
\hline NHT & 78,5366 & 74,8718 & 63,8519 & 73,4953 \\
\hline Make a Match & 71,8947 & 66,1714 & 66,1111 & 68,1468 \\
\hline Pembelajaran langsung & 65,6471 & 64,3478 & 59,3793 & 63,4312 \\
\hline Rerata marginal & 72,4248 & 68,3000 & 63,3261 & \\
\hline
\end{tabular}

Hasil Analisis Variansi Dua Jalan dengan Sel Tak Sama dapat dilihat pada Tabel 2.

Tabel 2 Rangkuman Perhitungan Uji Hipotesis dengan Analisis Variansi Dua Jalan

\begin{tabular}{lrrrrrc}
\hline \multicolumn{1}{c}{ Sumber } & \multicolumn{1}{c}{ JK } & \multicolumn{1}{c}{ dK } & \multicolumn{1}{c}{ RK } & \multicolumn{1}{c}{$\mathbf{F}_{\text {obs }}$} & $\mathbf{F}_{\text {tabel }}$ & Keputusanuji \\
\hline $\begin{array}{l}\text { Model pembelajaran } \\
\text { (A) }\end{array}$ & 4573,5204 & 2 & 2286,7602 & 10,7687 & 3,0243 & ditolak \\
Keterampilan sosial & 4255,0600 & 2 & 2127,5300 & 10,0189 & 3,0243 & ditolak \\
(B) & 1411,8472 & 4 & 352,9618 & 1,6622 & 2,4002 & diterima \\
Interaksi (AB) & 67103,0945 & 316 & 212,3516 & & & \\
Galat (G) & 77343,5221 & 324 & 10,7687 & & & \\
Total (T) & & & & & & \\
\hline
\end{tabular}

Berdasarkan Tabel 2 kesimpulan analisis variansi dua jalan dengan sel tak sama adalah:

(1) Pada efek utama antar baris (A), $\mathrm{H}_{0 \mathrm{~A}}$ ditolak, berarti terdapat perbedaan efektifitas dalam penggunaan model pembelajaran NHT, Make a Match dan langsung terhadap prestasi belajar matematika. (2) Pada efek utama antar kolom (B), $\mathrm{H}_{0 \mathrm{~B}}$ ditolak, berarti pada tingkat keterampilan sosial tinggi, sedang, dan rendah memberikan efek yang berbeda terhadap prestasi belajar matematika. (3) Pada efek interaksi $(A B), \quad H_{0 A B}$ diterima, berarti tidak terdapat interaksi antara model pembelajaran yang digunakan dan tingkat keterampilan sosial sama terhadap prestasi belajar matematika.

Pada model pembelajaran terdapat 3 kriteria, pada anava dua jalan menyebutkan bahwa ada perbedaan efektifitas penggunaan model pembelajaran terhadap prestasi belajar 
matematika. Oleh karena itu perlu dari ketiga model pembelajaran tersebut, dilakukan uji komparasi ganda antar baris untuk mengetahui mana yang baik seperti yang yang terangkum dalam Tabel 3.

Tabel 3 Rangkuman Uji Komparasi Rerata Antarbaris

\begin{tabular}{cccl}
\hline $\mathbf{H}_{\mathbf{0}}$ & $\mathbf{F}_{\mathbf{o b s}}$ & $\mathbf{F}=\mathbf{2} \mathbf{F}_{\text {tabel }}$ & \multicolumn{1}{c}{ Keputusan uji } \\
\hline$\mu_{1 .}=\mu_{2 .}$ & 7,2740 & 6,0486 & $\mathrm{H}_{0}$ ditolak \\
$\mu_{2 .}=\mu_{3 .}$ & 5,7071 & 6,0486 & $\mathrm{H}_{0}$ diterima \\
$\mu_{1 .}=\mu_{3 .}$ & 25,7545 & 6,0486 & $\mathrm{H}_{0}$ ditolak \\
\hline
\end{tabular}

Berdasarkan Tabel 3 dapat disimpulkan: ada perbedaan rerata yang signifikan antara prestasi belajar matematika siswa dengan model NHT dan Make a Match, juga ketika menggunakan model NHT dan pembelajaran langsung. Pada model Make a Match dan pembelajaran langsung ada kesamaan rerata prestasi belajar matematika. Hasil uji komparasi ganda antarbaris menyebutkan: rerata prestasi siswa pada model NHT lebih tinggi dibanding dengan Make a Match dan pembelajaran langsung, sedangkan dari model Make a Match memberikan rerata prestasi belajar yang sama dengan pembelajaran langsung, maka dapat disimpulkan bahwa siswa dengan NHT mempunyai prestasi belajar matematika yang lebih baik dibanding siswa dengan model Make a Match maupun pembelajaran langsung. Pada penelitian ini terdapat kesesuaian hasil penelitian dengan hipotesis yang diajukan. Model pembelajaran kooperatif khususnya NHT memberikan prestasi belajar yang lebih baik daripada model pembelajaran langsung sesuai dengan teori kognitif pada model pembelajaran kooperatif yang menekankan pengaruh kerja sama dalam suasana kebersamaan didalam kelompok itu sendiri. Menurut Slavin (1995:17), "cognitive theories emphasize the effects of working together in itself (whether or not the groups are trying of group goal)“. Pada model pembelajaran kooperatif tersebut, tidak akan terlihat siswa yang bekerja sendiri tanpa bantuan teman, karena pada tiap-tiap model yang tergolong dalam pembelajaran kooperatif semuanya mengutamakan kerja sama atau kerja kelompok dalam mengerjakan lembar kerja siswa. Hal ini sesuai dengan hipotesis yang diajukan, dan sejalan juga dengan Woods \& Chen (2010) yang menyatakan:

Cooperative learning is an instructional model in which student work together toward a common goal. Research has clearly shown that cooperation results in higher levels of achievement. Although students may be a part of a cooperative learning environment, they are also responsible for their own 
individual achievement. This makes student evaluations a chalenge because you are evaluating individual as well as team effort. This paper will review the alternatives for accesing the participation of individual students on a team as well as discuss the cases in which each approach was used. It identifies the positives and negatives of each approach.

Pada penelitian tersebut,

disimpulkan bahwa dengan

menggunakan model pembelajaran

kooperatif menunjukkan bahwa dengan berkelompok akan menghasilkan peningkatan hasil belajar. Selain itu juga sejalan dengan penelitian yang dilakukan oleh Apriandi (2012). NHT mempunyai kelebihan dalam mengapresiasikan diri dibandingkan dengan Make a Match dan pembelajaran langsung. Model NHT lebih unggul, karena interaksi antara siswa melalui diskusi dalam menyelesaikan masalah yang dihadapai, dan siswa pandai maupun siswa lemah sama-sama memperoleh manfaat melalui aktivitas belajar kooperatif. Dari Tabel 3, penggunaan model Make a match memberikan prestasi belajar matematika yang sama dengan pembelajaran langsung, hal ini tidak sesuai dengan hipotesis yang diajukan yaitu Make a
Match lebih baik daripada pembelajaran langsung. Dalam menerapkan suatu model pembelajaran terutama model kooperatif tipe Make a Match membutuhkan waktu yang bener-benar diperhitungkan, jadi apabila ketika model dilaksanakan dengan kurang memperhatikan waktu maka waktu yang digunakan selama proses pembelajaran berlangsung serasa sangat kurang, sehingga hal itu berpengaruh dengan materi yang disampaikan saat kegiatan belajar mengajar. Hal ini sejalan dengan penelitian yang dilakukan oleh Rijadi (2012) yang menyimpulkan bahwa siswa yang kurang kreatif, pada model Make a Match dengan pembelajaran langsung mempunyai prestasi yang sama.

Pada masing-masing keterampilan sosial, berdasarkan Tabel 1 menghasilkan kesimpulan terdapat perbedaan prestasi belajar pada siswa yang memiliki keterampilan sosial tinggi, sedang maupun rendah. Untuk melihat prestasi mana yang lebih baik pada masing-masing tingkat keterampilan sosial perlu dilakukan uji komparasi antarkolom. Uji antarkolom terangkum di Tabel 4. 
Tabel 4 Rangkuman Uji Komprasi Rerata Antarkolom

\begin{tabular}{cccc}
\hline $\mathbf{H}_{\mathbf{0}}$ & $\mathbf{F}_{\text {obs }}$ & $\mathbf{F}=\mathbf{2} \mathbf{F}_{\text {tabel }}$ & Keputusan uji \\
\hline$\mu_{.1}=\mu_{.2}$ & 4,3262 & 6,0486 & $\mathrm{H}_{0}$ diterima \\
$\mu_{.2}=\mu_{.3}$ & 6,3495 & 6,0486 & $\mathrm{H}_{0}$ ditolak \\
$\mu_{.1}=\mu_{.3}$ & 21,0503 & 6,0486 & $\mathrm{H}_{0}$ ditolak \\
\hline
\end{tabular}

Berdasarkan Tabel 4 dapat disimpulkan: ada perbedaan rerata yang signifikan antara prestasi belajar matematika pada siswa yang memiliki tingkat keterampilan sosial tinggi dan sedang dengan siswa yang memiliki tingkat keterampilan sosial rendah. Sedangkan siswa yang memiliki tingkat keterampilan sosial tinggi dengan sedang mempunya rerata prestasi belajar yang sama. Hal tersebut dapat dinyatakan begitu, karena rerata siswa dengan tingkat keterampilan tinggi dan sedang lebih tinggi dibandingkan dengan siswa dengan tingkat keterampilan sosial rendah, sedangkan dari uji komparasi antarkolom dinyatakan bahwa siswa yang berketerampilan sosial tinggi dan sedang memberikan prestasi belajar yang sama. Prestasi belajar matematika pada siswa yang memiliki keterampilan tinggi lebih baik daripada yang memiliki keterampilan rendah karena kemampuan bersosial sangat memberikan pengaruh dalam pemahaman suatu materi. Siswa yang mempuyai keterampilan sosial yang baik, akan mampu mengatasi kesulitan dalam memahami materi, dengan menanyakan ke teman maupun gurunya. Hasil tersebut sesuai dengan pendapat Sunarti (2009) menyimpulkan bahwa keterampilan sosial dimiliki seseorang jika ia telah mampu berosialisasi dengan orang lain dan menunjukkan sikap yang baik dan diterima di lingkungan tersebut. Hal inilah yang dibutuhkan siswa untuk mengoptimalkan hasil belajarnya dengan memiliki keterampilan sosial yang baik. Siswa yang memiliki keterampilan sosial rendah ketika mengalami kesulitan tidak mau menanyakan ke temannya, siswa cenderung diam. Sehingga kesimpulan dari pendapat Sunarti tersebut bisa dianggap sesuai dengan perolehan hasil penelitian ini.

Menurut Cartledge dan Milburn (1992:7),

In general, social skill are seen as socially acceptable learned behaviors that enable the person to interact with other in ways that elicit positive responses and assist in avoiding negatif responses from them.

Secara umum, keterampilan sosial dipandang sebagai perilaku yang dipelajari diterima secara sosial yang memungkinkan orang untuk berinteraksi dengan lain dengan cara yang menimbulkan tanggapan positif dan 
membantu dalam menghindari tanggapan negatif dari mereka. Dari pendapat tersebut berarti dengan memiliki keterampilan tinggi, lebih banyak mendatangkan dampak yang positif. Dengan demikian dapat disimpulkan bahwa siswa dengan tingkat keterampilan sosial tinggi dan sedang mempunyai prestasi belajar matematika yang sama baik, siswa dengan tingkat keterampilan sosial tinggi dan sedang mempunyai prestasi belajar matematika lebih baik daripada siswa dengan tingkat keterampilan sosial rendah. Sesuai dengan penelitian Sudarmono (2009) yang menyatakan peserta didk yang berketerampilan sosial tinggi, perolehan prestasi belajarnya lebih baik daripada yang berketerampilan sosial rendah.

\section{SIMPULAN DAN SARAN}

Berdasarkan pembahasan hasil penelitian dapat disimpulkan bahwa pada kelas X SMK di Wonogiri Semester Gasal Tahun Ajaran 2012/2013:

Prestasi belajar matematika siswa yang menggunakan model pembelajaran kooperatif tipe NHT lebih baik daripada siswa yang menggunakan model pembelajaran kooperatif tipe Make a Match maupun pembelajaran langsung, sedangkan prestasi belajar matematika siswa yang menggunakan model pembelajaran kooperatif tipe Make a Match lebih baik daripada pembelajaran langsung.

Siswa yang memiliki keterampilan sosial tinggi dan sedang, menghasilkan prestasi belajar matematika yang sama, sedangkan prestasi belajar matematika siswa yang memiliki keterampilan sosial tinggi dan sedang lebih baik daripada siswa yang memiliki keterampilan sosial rendah.

Pada masing-masing keterampilan sosial (tinggi, sedang, dan rendah), prestasi belajar matematika siswa yang menggunakan model pembelajaran kooperatif tipe NHT lebih baik daripada siswa yang menggunakan model pembelajaran kooperatif tipe Make a Match maupun pembelajaran langsung, dan prestasi belajar matematika siswa yang menggunakan model pembelajaran kooperatif tipe Make a Match lebih baik daripada pembelajaran langsung.

Pada model pembelajaran (NHT, Make a Match, dan pembelajaran langsung), siswa yang memiliki keterampilan sosial tinggi dan sedang, mempunyai prestasi belajar matematika yang sama, sedangkan prestasi belajar matematika siswa yang memiliki keterampilan sosial tinggi dan sedang lebih baik daripada siswa yang memiliki keterampilan sosial rendah. 
Berdasarkan penelitian ini dapat dikemukakan beberapa saran sebagai berikut:

1. Bagi kepala sekolah

a. Hendaknya memberikan contoh kepada guru dan siswa, untuk selalu bekerja sama dan menjalin hubungan baik dengan orang lain, karena hal itu merupakan ciri bahwa seseorang mempunyai keterampilan sosial tidak rendah.

b. Hendaknya memberikan dorongan dan menerapkan kebijakan bagi guru untuk menggunakan model pembelajaran yang mutakhir dan merangsang keaktifan siswa di kelas pada pembelajaran matematika. Model pembelajaran yang dapat diterapkan diantaranya adalah NHT dan Make a Match yang terbukti mampu meningkatkan hasil belajar matematika siswa.

2. Bagi guru matematika

a. Guru matematika hendaknya lebih sering menggunakan model pembelajaran NHT dalam proses belajar mengajar, karena model ini lebih efektif disbanding pembelajaran langsung. NHT mampu meningkatkan hasil belajar siswa dan juga keaktifan siswa di kelas serta membuat kegiatan belajar mengajar lebih menyenangkan.

b. Guru matematika dapat menerapkan model pembelajaran Make a Match dalam kegiatan belajar mengajar. Model ini terbukti mampu memberikan pengaruh hasil belajar siswa dibandingkan model pembelajaran konvensional atau pembelajaran langsung. Penerapan Make a Match secara tepat akan merangsang siswa untuk lebih aktif di kelas dan berusaha memahami materi dengan berdiskusi. Model ini sangat cocok untuk diterapkan pada mata pelajaran matematika dengan kondisi kemampuan anak yang berbeda-beda.

3. Bagi siswa

a. Siswa harus lebih antusias ketika mengikuti kegiatan belajar mengajar di kelas dan saat guru mencoba menerapkan model pembelajaran baru, seperti NHT. Model pembelajaran yang baik tidak akan menampakkan hasilnya jika 
siswa tidak antusias dan aktif mengikuti arahan guru. Jadi, keberhasilan pencapaian hasil belajar terletak pada antusias siswa dalam menerapkan NHT di kelas.

b. Siswa diharapkan dapat mengembangkan keterampilan sosialnya agar dapat memacu hasil belajar. Keterampilan social terbukti mampu memberikan dampak positif terhadap hasil belajar, karena siswa mudah untuk bersosialisasi dengan temannya dan dapat berdiskusi ketika bekerjasama. Hal ini tentu akan memberikan pengaruh terhadap pemahaman materi yang lebih baik terhadap siswa, sehingga siswa memang diharapkan untuk lebih meningkatkan keterampilan sosialnya dan tentu juga belajarnya.

4. Bagi Peneliti

a. Hasil penelitian ini dapat digunakan sebagai referensi penelitian yang sejenis khususnya yang berkaitan dengan model pembelajaran NHT dan Make a Match.

b. Model penelitian ini dapat dikembangkan dengan model pembelajaran yang lain dengan tinjauan yang sama, yaitu keterampilan sosial. Ataupun juga dengan menggunakan salah satu variabel model pembelajaran dan dengan tinjauan yang berbeda untuk mengetahui keefektivitasan hasil belajarnya.

\section{DAFTAR PUSTAKA}

Apriandi, D.. 2012. Efektivitas Model Pembelajaran Kooperatif Tipe Two Stay-Two Stray (TS-TS) dan Numbered Heads Together (NHT) terhadap Prestasi Belajar Matematika Siswa Kelas VIII SMP di Kabupaten Bantul Ditinjau dari Aktivitas Belajar.Tesis. Program Pascasarjana UNS. Surakarta.

Budiyono. 2009. Statistika Untuk Penelitian.Edisi ke2.Surakarta : UNS Press.

Cartledge, G. \& Milburn, J. F.. 1992. Teaching Social Skill to Children Innovative Approach. New York: Pergamon Press.

Ibrahim, M.. 2000. Pembelajaran Kooperatif. Surabaya: Universitas Negeri Surabaya.

Maheady, L., Michielli, J., Harper, F., dan Mallette, B.. 2006. "The Effects of Numbered Heads Together with and Without an Incentive Package on the Science Test Performance of a Diverse Group of Sixth Graders". Journal of Behavioral Education, Vol. 
15, No. 1, March 2006 ( $C_{-}$ 2006), pp. 25-39.

\begin{tabular}{lr} 
Munawar.I..2009. & \multicolumn{2}{r}{ Implementasi } \\
Cooperative Learning Tipe & Tead \\
Numbered & Head \\
Together $($ NHT) & Untuk \\
Meningkatkan Partisipasi dan \\
Hasil Belajar Siswa dalam \\
Pembelajaran Matematika di \\
Kelas VIII MTS N \\
Gondowulung Bantul. Tesis. \\
UIN Sunan Kalijaga. \\
Yogyakarta
\end{tabular}

Rijadi, S.. 2012. Eksperimentasi Model Pembelajaran Konvensional, Make a Match dan Systhematic Approach to Problem Solving dalam Pembelajaran Matematika Ditinjau dari Kreativitas Siswa Kelas XI SMA Negeri di Kabupaten Banyumas. Tesis. Program Pascasarjana UNS. Surakarta.

Satyawati, R.. 2009. Upaya Meningkatkan Minat Belajar Matematika Siswa Kelas VIII SMP Negeri 1 Jetis Bantul dengan Model Cooperative Learning Tipe Make A Match. Tesis. Universitas Negeri Yogyakarta. Yogyakarta.

Slavin, R.. 2005. Cooperative Learning Teori, Riset dan Praktik. Bandung: Nusa Media.

Sunarti, E.. 2005. Ajarkan Anak Keterampilan Hidup Sejak Usia Dini. Jakarta: PT Elex Media Komputindo.

Sudarmono, A.. 2009. Pembelajaran Fisika melalui Metode Mencari Pasangan dan Bertukar Pasangan ditinjau dari Keterampilan Sosial dan kemampuan Aljabar Siswa (Studi Kasus pembelajaran Fisika Materi Pokok Suhu dan
Kalor pada Siswa Kelas X SMA N1 Karas Kabupaten Magetan tahun Pelajaran 2008/2009. Tesis. Program Pascasarjana UNS. Surakarta.

Suprijono, A.. 2009. Cooperatif Learning. Yogyakarta: Pustaka Pelajar.

Wahyu, Y.. 2011. Efektivitas Model Penemuan Terbimbing dan Cooperative Learning Ditinjau dari Kreativitas Siswa pada Pembelajaran Matematika di Kelas IX SMP Se-Sub Rayon 04 Kabupaten Wonogiri Tahun Pelajaran 2010/2011. Tesis. Program Pascasarjana UNS. Surakarta.

Woods, D. M \& Chen, K. C. 2010. "Evaluation Techniques for Cooperative Learning". International Journal of Management and Information Systems. 14(1). 1-5. 